\title{
Perubahan Struktur Organisasi Kepanitiaan dalam Festival Film Mahasiswa UCIFEST
}

\author{
Natalia Depita ${ }^{\mathrm{a}, 1, *}$ \\ ${ }^{\text {a }}$ Program Pascasarjana Institut Seni Indonesia Jl. Ki Hadjar Dewantoro No. 19 Surakarta 57126, Indonesia \\ natalia.depita91@gmail.com* \\ * Corresponding Author
}

Received 2019-07-16; accepted 2020-08-11; published 2020-08-19

\begin{abstract}
ABSTRAK
Festival film berkontribusi besar dalam menyelesaikan masalah distribusi bagi film-film alternatif seperti film-film karya mahasiswa yang ada di Indonesia. Film -film mahasiswa yang tidak dapat masuk ke jalur komersil, membutuhkan ruang atau etalase untuk menunjukkan karya mereka. Kebutuhan akan memiliki ruang eksebisi dan distribusi bagi film-film alternatif, menjadi faktor terbentuknya festival-festival film kampus. Sebagai festival film yang berada dibawah institusi dan dibentuk dengan semangat independen dari mahasiswa, festival film dapat bertahan dalam berbagai kondisi. Jaringan yang diciptakan oleh mahasiswa antar universitas juga menjadi kekuatan berlangsungnya festival film. Struktur organisasi kepanitiaan dibuat menyesuaikan kebutuhan festival film. Struktur organisasi yang dibentuk harus berjalan secara efektif dan efisien demi tercapainya kesuksesan festival film.
\end{abstract}

\section{Changes in the Organizational Structure of the Committee in the UCIFEST Student Film Festival}

\section{ABSTRACT}

Film festivals contribute to solving distribution for alternative films. A short film created by students cannot enter the commercial path or screen in the movie theatre. The need to have exhibition and distribution spaces for the alternative film is a factor that the students make short film festivals on the campus. As a film festival under the university or institution, a film festival can survive in various conditions. This is because of the festival formed with the spirit of independence by students. Besides that, the network created by students between the communities or universities is also the strength of the short film festival. Another essential factor for the film festival is the organizational structure. The organizational structure must run effectively and efficiently to achieve the success of the film festival.

\section{KEYWORDS}

Student Film Festival; Organizational

structure; Exhibition, Alternative Film Distribution.

This is an openaccess article under the CC-BY-SA license

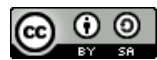

\section{Pendahuluan}

Film pendek di Indonesia muncul sebagai media komunikasi suatu komunitas atau individu untuk menyampaikan ekspresi personal. Sebagai sebuah media untuk berekspresi, tema yang diangkat dalam film pendek sangat beragam, yang seringkali tidak ditemui pada film-film komersil yang beredar di bioskop. Karena bersifat independen film pendek biasanya penuh dengan eksplorasi subyektif dari pembuat film. Sebagai film alternatif, sistem distribusi film pendek tidak terintegrasi dengan bioskop maupun televisi. Film dibuat untuk ditonton, namun ketiadaan ruang sering menjadi isu yang membuat film pendek tidak beredar luas di masyarakat. Film pendek merupakan film alternatif yang produksi dan distribusinya dikerjakan dengan semangat independen atau mandiri. Festival film merupakan jawaban atas permasalahan distribusi dan eksebisi film-film alternatif. Festival film dikatakan merupakan titik temu dari berbagai kalangan penonton serta pelaku dunia perfilman (Jesika Ismail 2017). Perkembangan film yang di sebuah negara, dapat dilihat dari festival-festival film yang ada di 
negara tersebut. Salah satu hal yang menarik untuk diamati yaitu festival film kampus yang diinisiasi oleh mahasiswa. Di dalam festival film yang diselenggarakan di kampus, kita dapat menemukan banyak film-film pendek yang segar dan baru. Film-film ini memiliki warna dan karakter tersendiri dalam industri perfilman di Indonesia, yang tidak dapat dijumpai di bioskop-bioskop komersil. Pasar kompetisi film dikuasai oleh mayor label perusahaan film, sehingga film-film alternatif atau film-film independen akan kesulitan masuk dalam sirkuit jalur distribusi industri film. Festival film merupakan alternative distribution platform bagi pembuat film untuk mendistribusikan karyanya (Banjaransari 2019). Festival tidak hanya sebagai titik pertemuan antara pembuat film dengan penontonnya, tetapi juga sebagai marketplaces bagi film-film alternatif. Festival sebagai marketplaces dibedakan menjadi event wholesale dan retail (Bachmann 2000). Wholesale atau grosir secara substansial bertindak sebagai pasar tempat agen penjualan menjual film, sedangkan retail secara esensial sebagai eksibitor. Festival wholesale berkisar pada bisni pasar bioskop niche yang berisiko tetapi berpotensi menguntungkan ketika ada kesesuaian antara kebutuhan khusus dengan kualitas produk yang ditawarkan. Di sisi lain, festival retail memenuhi fungsi lokal dengan menampilkan film-film yang tidak (belum) tersedia di bioskop umum untuk masyarakat dari sekitar wilayah tersebut. Kehadiran art house exhibition dan festival-festival film independent menjadi metode distribusi alternatif. Di Indonesia sendiri, ada beberapa universitas yang menyelenggarakan festival film. Festival film dibuat sebagai wadah bagi komunitas film untuk menunjukkan karyanya kepada publik. Beberapa festival film mahasiswa, diantaranya Malang Film Festival (MAFI Fest), Solo Documentary Film Festival (SODOC), UCIFEST, Pesta Film Solo, UI Film Festival (Jesika Ismail 2017). Festival-festival yang disebutkan konsisten menjadi acara tahunan yang diinisiasi oleh mahasiswa.

UCIFEST merupakan salah satu festival film mahasiswa, yang berlangsung sejak tahun 2011 dan masih secara konsisten diselenggarakan setiap tahun. Festival ini pertama kali diiniasi di kelas Digital Cinematography I, mahasiswa membutuhkan etalase untuk melakukan eksebisi karya film sebagai tugas mata kuliah, maka UCIFEST I diselenggarakan pada 5 Januari 2011 untuk pertama kali. UCIFEST mulanya dikhusukan untuk mahasiswa peminatan film dan animasi di Universitas Multimedia Nusantara. Setelah penyelenggaraan yang pertama, reaksi yang begitu besar dari mahasiswa UMN, mendorong panitia festival untuk menyelenggarakan kembali dan melibatkan fakultas dan bahkan universitas lain. Tahun ini merupakan tahun kedelapan terselenggaranya UCIFEST dan telah banyak perubahan dan perkembangan yang terjadi. Kompetisi film yang dulunya bersifat internal antar fakultas telah berkembang menjadi skala nasional.

Setiap tahunnya jumlah peserta makin bertambah dari kategori SMA, mahasiswa, bahkan umum. UCIFEST menjadi salah satu festival film kampus yang ditunggu-tunggu setiap tahunnya, sehingga sangat menarik untuk dibahas dan diangkat. UCIFEST yang dulunya diinisiasi oleh dosen dan mahasiswa sekarang telah berkembang menjadi festival film yang dikenal khalayak ramai. Mata kuliah Festival Film pun dibentuk, untuk lebih memetakan festival film di Indonesia, yang diajar oleh Lulu Ratna. Lulu Ratna sebagai salah satu pengamat festival film di Indonesia, menjadi dosen sekaligus advisor dalam penyelenggaran UCIFEST selama 3 tahun terakhir. Lulu Ratna merupakan sosok yang sering ditemui diberbagai festival film yang berlangsung di Indonesia. Beliau begitu memahami seluk beluk serta pemetaan dunia perfilman di Indonesia khususnya festival film. Maka, akan sangat menarik untuk membaca festival film UCIFEST berdasarkan sudut pandang seorang Lulu Ratna.

\section{Deskripsi Obyek}

\subsection{Festival Film Mahasiswa di Indonesia}

Festival film di Indonesia sendiri dimulai pada tahun 1955, yang dinamakan Festival Film Indonesia (FFI). FFI yang dulu dinamai Pekan Apresiasi Nasional, kembali diselenggarakan untuk kedua kalinya pada 1960. Semenjak 1973 FFI rutin diselenggarakan setiap tahun dan menghadirkan film-film terbaik yang diproduksi di Indonesia. Festival film ini diselenggarakan sebagai bentuk apresiasi kepada para pembuat film yang ada di Indonesia masa itu. Film-film yang dihadirkan merupakan film-film panjang yang beredar di bioskop dan layar TV. Festival ini pun sempat berhenti beberapa kali, pada tahun 1993 dan 2004. FFI menjadi wadah apresiasi bagi film-film panjang yang tayang di layar lebar. Lalu, bagaimana dengan perkembangan film-film pendek di Indonesia. Paska 
orde baru terjadi kebangkitan film Indonesia, salah satunya ditandai dengan munculnya festival film pendek yang diberi nama Festival Film \& Video Independen Indonesia (Konfiden).

Festival Film \& Video Independen, merupakan penanda perkembangan film-film pendek yang diproduksi secara Independen di Indonesia, festival ini kemudian berganti nama menjadi Festival Film Konfiden. Meskipun Konfiden tidak aktif semenjak tahun 2009, namun sejak festival ini mulai bermunculan festival-festival film pendek lainnya di ranah kampus maupun umum. Festival film yang terdapat diseluruh dunia terbagi ke dalam beberapa kategori. Pilihan kategori didasarkan pada perbedaan showcase pada festival film. Misalnya, festival untuk film panjang atau pendek, film fiksi atau dokumenter, animasi atau film eksperimental. Selain itu ada juga pengelompokkan berdasarkan program yang dibuat oleh suatu festival, ada festival yang memilih film tidak berdasarkan durasi, format, atau genre, tetapi berdasarkan tema dan konteks yang diangkat.

Valck secara umum membagi festival film kedalam empat kategori yang terdiri dari : (1) Identity Base Film Festival, (2) Genre Base Film Festival, (3) National \& Regional Showcase, (4) Online Film Festival (De Valck 2007). Berdasarkan pembagian kategori diatas festival film yang diinisiasi oleh mahasiswa dan dilaksanakan dibawah suatu institusi termasuk dalam Identity Base Film Festival dan National \& Regional Showcase. Identity Base Film Festival merupakan festival film yang dibuat berdasarkan identitas dan komunitas yang ada di suatu daerah tertentu. Identitas sebagai mahasiswa dan pembuat film independent membentuk suatu komunitas yang menyelenggarakan sebuah festival film. Dalam kategori National \& Regional Showcase, festival film dipengaruhi oleh geopolitik dan berlangsung di suatu lingkung daerah atau wilayah.

Rangkaian festival film, sebagai jalur distribusi alternatif mempengaruhi masyarakat sekitar, program-program film yang dihadirkan, serta kehidupan ekonomi. Terdapat beberapa festival film kampus, yaitu UI Film Festival semenjak tahun 2014, Ganesha Film Festival (Ganffest) sejak tahun 2008, Malang Film Festival (MAFI Fest) sejak 2004 dan UCIFEST sejak tahun 2011. Setiap festival memiliki karakter dan warna yang cukup berbeda dari yang lainnya, meskipun memiliki program acara yang cukup sama. Dalam festival film mahasiswa, akan ditemui pemutaran film, program kompetisi, seminar, workshop, dan malam penghargaan.

Malang Film Festival (MAFI FEST) adalah festival film tahunan tingkat pelajar dan mahasiswa yang diadakan di Malang. Banyak pembuat film asal Malang yang mengawali karir sebagai pembuat film lewat kompetisi yang diadakan oleh festival ini. MAFI FEST terselenggara sejak tahun 2004, festival ini diprakarsai oleh Kine Klub Universitas Muhammadiyah Malang (UMM). Festival ini diselenggarakan setiap tahunnya di bulan April, dengan dua program utama kompetisi dan nonkompetisi. Kategori kompetisi, terdiri atas Fiksi Pendek Mahasiswa, Fiksi Pendek Pelajar, Dokumenter Pendek Mahasiswa, dan Dokumenter Pendek Pelajar. Festival ini dikenal di kalangan mahasiswa dan menjadi salah satu festival kampus yang bergengsi. MAFI FEST yang telah berlangsung selama lebih dari 13 tahun, membantu perputaran roda ekosistem perfilman di Indonesia khususnya untuk film-film alternatif. Disamping itu, festival ini juga menjadi ruang diskusi dan pertukaran informasi, sekaligus ruang untuk membangun koneksi dan menambah wawasan. Dengan jumlah penonton lebih dari 1500 orang setiap tahunnya, festival ini menjadi sebuah event tahunan yang penting di kota Malang.

Universitas Indonesia (UI) Film Festival adalah festival film lain di tingkat mahasiswa yang diselenggarakan oleh unit kegiatan mahasiswa (UKM) Sinematografi UI. Festival ini mempunya gagasan "dari mahasiswa, untuk mahasiswa". Gagasan yang diangkat mencerminkan hasil kurasi film-film yang dipertontonkon serta kegiatan pendukung yang diadakan. UI Film Festival diadakan sejak tahun 2014 setiap bulan September. Festival ini terdiri atas dua kategori kompetisi dan nonkompetisi, yang terbagi kedalam 7 program. Kategori kompetisi, terdiri atas Film Pendek, Esai Perfilman dan Film Parodi. Kategori non-kompetisi terdiri atas Shorties on Screen, Sinema Kaki Lima, Special Screening, Pemutaran Finalis Kompetisi Film Pendek.

Fokus dari festival film ini adalah karya-karya film yang diproduksi oleh mahasiswa. Selama empat tahun berjalan, festival ini melakukan inovasi-inovasi terhadap program festival yang membuatnya semakin berkembang. Dalam penyelenggaraannya UI Film Festival menjalin kerjasama dengan organisasi-organisasi film yang berbasis di luar kampus, sehingga dapat membuka wawasan baru mengenai perkembangan film alternatif. Festival film seperti ini dapat menumbuhkembangkan talenta mahasiswanya dalam membuat dan mengapresiasi film. 
UMN Cinema Festival (UCIFEST) pertama kali diselenggarakan pada 5 Januari 2011. UCIFEST secara konsisten membuka pendaftaran sampai ke tingkat nasional. Festival yang berlangsung setiap bulan November ini menjadi media pembelajaran bagi mahasiswa jurusan film di kampus UMN untuk mengasah kemampuan pembuatan film dan pemrograman festival film. Hal ini terlihat dari kualitas film-film mahasiswa UMN yang semakin baik setiap tahunnya. Kategori kompetisi dalam Festival Film UCIFEST terdiri atas Film pendek fiksi tingkat SMA/SMK Nasional, Film pendek animasi tingkat SMA/SMK Nasional, Film pendek fiksi tingkat mahasiswa nasional, film pendek animasi tingkat mahasiswa nasional dan Film pendek dokumenter tingkat mahasiswa nasional. Dalam program non-kompetisi UCIFEST, mengadakan program seminar dan masterclass yang menghadirkan praktisi-praktisi ternama di industri perfilman. Sampai saat ini UCIFEST menjadi festival film terbesar yang diadakan mahasiswa di daerah Tangerang dengan ajang kompetisi tigkat nasional.

\subsection{Perkembangan Festival Film Mahasiswa UCIFEST}

UCIFEST yang dulunya bernama Ultima Cinema Festival, yang diselenggarakan oleh Universitas Multimedia Nusantara (UMN). Festival ini dibentuk sebagai etalase bagi mahasiswa peminatan digital cinematography (sekarang menjadi program studi film) untuk memamerkan karya mereka. Maka, tercetuslah ide untuk membuat sebuah festival film dalam lingkungan internal, dan diberi nama Ultima Cinema Festival (ULCIFEST). Ultima sendiri merupakan singkatan dari Universitas Multimedia Nusantara, yang kemudian diganti menjadi UMN. UCIFEST-UMN (Universitas Multimedia Nusantara) Animation \& Film Festival merupakan festival film kampus pertama yang diselenggarakan di Tangerang.

Film-film yang diputar merupakan hasil karya dari kelas digital cinematography I, digital cinematography III, animasi 2D, animasi 3D, dan stopmotion dibawah Fakultas Seni dan Desain program studi Film dengan peminatan film dan animasi. Saat pertama kali dibentuk festival ini bertujuan untuk menumbuhkan rasa percaya diri bagi mahasiswa dalam menunjukkan karyanya ke publik, serta menunjukkan eksistensi mahasiswa peminatan film dan animasi dari Fakultas Seni dan Desai di UMN. Selain itu festival ini juga menjadi ajang promosi Universitas Multimedia Nusantara sebagai universitas baru di wilayah Tangerang kepada masyarakat dan siswa SMA.

Peserta ULCIFEST I pertama terdiri dari mahasiswa program studi DKV yang mengambil peminatan digital cinema dan animasi. Festival ini memiliki 8 kategori penghargaan, yaitu Best Effect, Best Story, Best Artistic Picture, Best Cinema, Best 2D Animation, Best 3D Animation, dan Best Stopmotion. Acara ULCIFEST I terlaksana dengan sukses dan dihadiri lebih dari 300 dari kalangan siswa SMA dari wilayah Gading Serpong, Tangerang. ULCIFEST 2 kembali diselenggarakan pada 12 - 13 Oktober 2011. ULCIFEST 2 memiliki 11 kategori penghargaan, dengan penambahan pada kategori Best Documentary, Best TVC, Best Poster, dan Favorite Movie pilihan penonton.

Selain program kompetisi, ULCIFEST 2 juga menyelenggarakan program non-kompetisi berupa seminar yang dibawakan oleh Nia Dinata, sineas perfilman Indonesia. Peserta yang mulanya hanya mahasiswa DKV UMN pun bertambah menjadi siswa SMA, ada 17 film dari siswa SMA yang diputar dalam festival film ULCIFEST 2. Dalam 8 tahun terakhir UCIFEST berkembang pesat. Saat penyelenggaraan yang kesepuluh di tahun 2019, terdapat lebih dari 300 karya film pendek fiksi, dokumenter dan animasi baik dari tingkat mahasiswa maupun pelajar SMA. Kualitas film yang dihadirkan pun semakin baik dan beragam. Dalam penyelenggaraan setiap tahunnya, tidak ada tema khusus yang diangkat, sehingga film pendek dengan tema apapun dapat didaftarkan dalam festival film ini.

\subsection{Struktur Organisasi Kepanitiaan UCIFEST}

Festival yang mulanya diinisiasi oleh dosen dan mahasiswa ini mendapat respon positif dari publik dan kampus lainnya. UCIFEST I yang terdiri dari 20 panitia dan dosen, sekarang telah berkembang menjadi 40 panitia, pada Figure 1. Dalam perkembangannya struktur organisasi pun mengalami perubahan, menyesuaikan dengan skala festival. Festival yang mulanya ditujukan untuk internal mahasiswa DKV UMN pun berkembang menjadi salah satu festival film kampus skala nasional. 


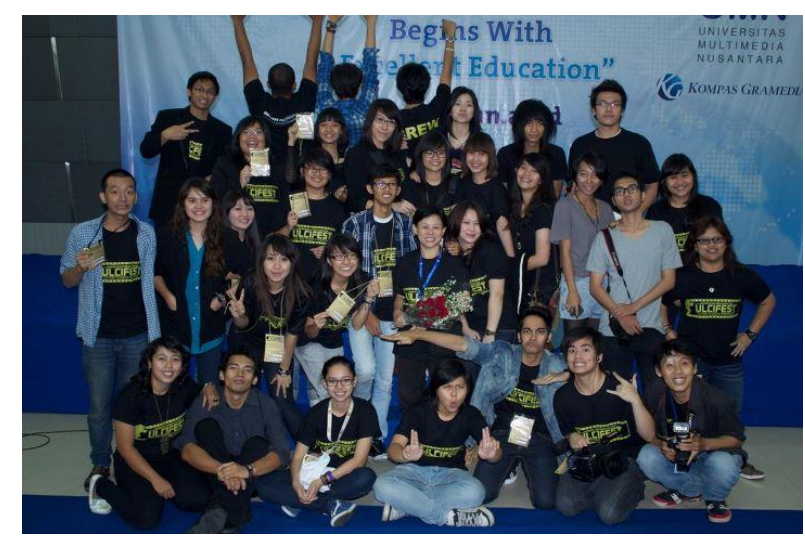

Fig. 1. Seluruh Panitia UCIFEST 1

Tahun ini merupakan penyelenggaraan UCIFEST yang kesepuluh. Selama delapan tahun berjalan festival film UCIFEST mengalami berbagai perkembangan dan penyesuaian baik dalam program festival maupun struktur organisasi, Figure 2. Salah satu faktor yang menyebabkan UCIFEST dapat bertahan sampai saat ini yaitu adanya estafet kepemimpinan dari angkatan senior ke angkatan di bawahnya. Semangat independen yang dimiliki mahasiswa dalam mewujudkan sebuah festival film terlihat dari acara yang diselenggarakan setiap tahun ini. Festival yang berkembang menjadi skala nasional tidak lepas dari perkembangan Fakultas Seni dan Desain di UMN. Digital cinematography yang dulunya peminatan di bawah program studi Desain Komunikasi Visual telah berubah menjadi program studi sendiri, yaitu Film dengan peminatan film dan animasi. Hal ini mengasah kualitas mahasiswa dalam berkarya. Selain itu di bawah program studi film dibentuk kelas festival film sebagai media pembelajaran bagi mahasiswa untuk memahami seluk beluk dunia festival film. Dengan adanya kelas festival film, festival film UCIFEST pun semakin terarah dan terkenal di antara festival film kampus lainnya.

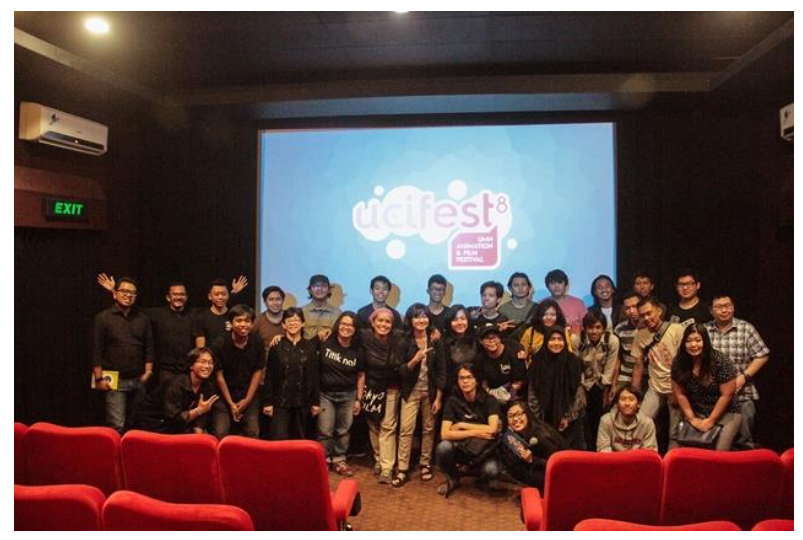

Fig. 2.Tim Panitia UCIFEST 8

\subsection{Perspektif Lulu Ratna tentang Festival Film Mahasiswa}

Lulu Ratna merupakan pengajar kelas Festival Film di Universitas Multimedia Nusantara (UMN), selain sebagai pengajar Lulu Ratna dikenal sebagai 'ibu' festival film yang ada di Indonesia. Malang melintang lebih dari 20 tahun dalam dunia festival, membuat beliau paham seluk beluk setiap festival film yang ada di Indonesia. Sebagai lulusan antropologi FISIP-UI, Lulu Ratna aktif di organisasi Boemboe Forum dan pernah bekerja di beberapa festival baik di Indonesia maupun internasional. Lulu Ratna saat ini banyak memberi workshop festival film bersama COFFIE (Coordination for Film Festival in Indonesia) serta aktif sebagai anggota Komite Dewan Kesenian Jakarta. Menurut Lulu Ratna, festival film merupakan sebuah event perayaan, dimana orang-orang yang berkepentingan di dunia film berkumpul. Disana orang-orang akan berkumpul dan berbagi karya, ide, dan pengetahuan dalam bentuk pemutaran film, diskusi dan seminar. Menurut Lulu Ratna, festival film merupakan 
kerja kolaboratif yang membentuk sebuah ekosistem perfilman yang saling berkesinambungan. Festival-festival film yang ada memiliki statement nya masing-masing dan ini menjadi warna dalam industri perfilman Indonesia. Festival film yang berada dibawah universitas dapat bertahan lama, karena adanya semangat independen dalam menggelar sebuah event.

\section{Analisis Obyek}

\subsection{Analisa Perkembangan Festival Film Mahasiswa}

Festival film merupakan kerja kolaboratif dari berbagai pihak yang terlibat dan memiliki kepentingan. Ekosistem festival film terbentuk dari: (1) organizer atau pelaksana festival, (2) pemberi dana, (3) sponsor, (4) tempat acara festival, (5) media partner, dan (6) komunitas film. Enam hal ini menjadi motor penggerak sebuah festival film. Jika salah satu elemen diatas tidak ada maka sebuah festival tidak dapat berjalan. Malang Film Festival (MAFI FEST) merupakan festival film kampus yang tertua dan masih eksis sampai saat ini, lihat Figure 3. Festival yang dimulai dari unit kegiatan mahasiswa (UKM) Kine Klub Universitas Muhammadiyah Malang ini telah menjadi festival kampus tingkat nasional. Tahun 2019 merupakan kali ke-15 terselenggaranya kompetisi film bagi para sineas muda berbakat di kota Malang. Mulanya event ini dilaksanakan secara independen oleh mahasiswa anggota Kine Klub UMM, namun sekarang didukung oleh Pusbang Film.

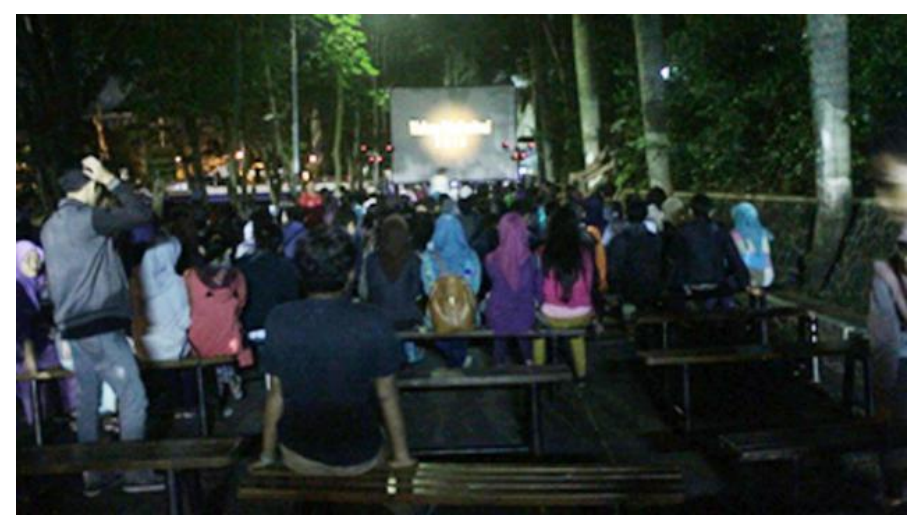

Fig. 3.Suasana Layar Tancap di MAFI FEST, Malang

Tahun ini MAFI FEST juga didukung oleh penyedia layanan streaming, Viu Indonesia melalui program kerjasama pitching forum. Program pitching forum merupakan bentuk dukungan dari Viu Indonesia bagi sineas-sineas muda khususnya di kota Malang untuk mewujudkan ide ceritanya. Tidak hanya pitching forum, MAFI Fest juga mengadakan program non-kompetisi seperti Malam Penghargaan, Sesi Malangan, program penayangan khusus, program penayangan perdana, dan kelas kritik film, Figure 4.

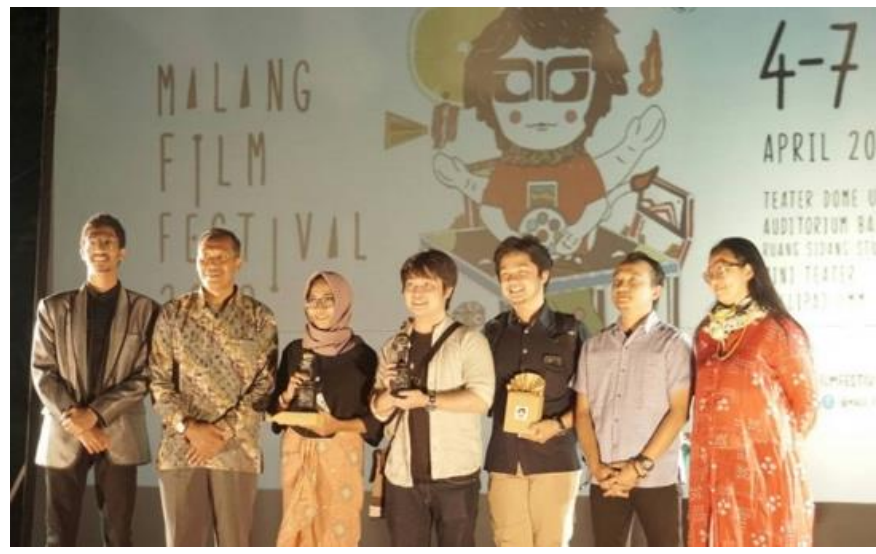

Fig. 4. Malam Penghargaan MAFI FEST 2018 
Dalam program sesi Malangan, film-film yang diputar adalah film-film yang diproduksi oleh orang-orang Malang. Melalui film ini kita dapat melihat isu-isu terkait nilai lokalitas yang ada di kota Malang, selain itu dapat ditemui gaya bahasa dan bercandaan khas masyarakat kota Malang. Festival kampus lainnya yaitu Universitas Indonesia Film Festival (UI Film Festival) pada Figure 5, yang berlangsung sejak tahun 2014. Acara ini bertujuan untuk wadah apresiasi dan kontribusi mahasiswa se-Indonesia yang memiliki bakat dan minat dalam bidang perfilman. Festival ini mempunyai gagasan "dari mahasiswa untuk mahasiswa", hal ini tercermin dalam kurasi film yang dipertontonkan. Disamping itu festival ini memutar film-film negara tetangga di Kawasan ASEAN, bekerjasama dengan Jogja NETPAC Asian Film Festival (JAFF) melalui program Mosean Picture. Mosean Picture memutarkan 4 film karya sineas dari Asia Tenggara, program ini diharapkan dapat memberi kesegaran tontonan dan referensi bagi penonton UIFF.

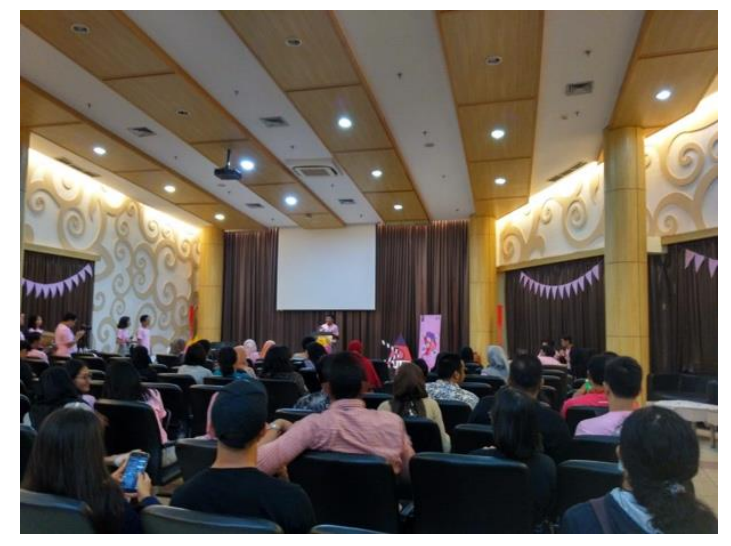

Fig. 5.Suasana screening film UI Film Festival, Depok

Program lain yang menarik dari UIFF yaitu Sinema Kaki Lima, yang memutarkan film dengan konsep outdoor layar tancap, dilengkapi dengan jajanan gerobak bak layar tancap tempo dulu. Program ini bertujuan menghadirkan nuansa pemutaran film yang klasik dan menjadi salah satu cara untuk bernostalgia bagi penonton. Terdapat dua kesamaan dari MAFI FEST dan UI Film Festival dimana semua acara yang diselenggarakan terbuka untuk umum dan tidak memungut biaya dari penonton. Hal ini dikarenakan festival yang diinisiasi mahasiswa menjunjung semangat independent dan menjalin ruang antar komunitas.

\subsection{Analisis Karakter Film yang Diputar di Festival Film UCIFEST}

Film-film alternatif yang diputar dalam festival film, memberikan warna tersendiri dalam industri perfilman. Film-film pendek karya mahasiswa biasanya mengangkat isu tentang keseharian anak-anak muda dan permasalahan kehidupannya sehari-hari. Film-film ini bertutur dengan simpel dan sederhana dalam durasi yang pendek. Namun dibalik kesederhanaannya terdapat cerita-cerita yang tidak dapat kita temui di bioskop.

\subsection{Analisis Perubahan Struktur Kepanitiaan di UCIFEST}

Struktur kepanitiaan sebuah acara berperan penting atas terselenggaranya festival film. Festival Film UCIFEST dapat berlangsung sampai dengan saat ini karena adanya estafet kepanitiaan dari angkatan senior ke angkatan dibawahnya. Mulanya panitia UCIFEST terdiri dari mahasiswa dan dosen. Dosen berperan sebagai Pembina organisasi sekaligus supervisor. Struktur awal organisasi UCIFEST terdiri dari:

- Supervisor bertugas sebagai penasihat dan pengawas pelaksanaan UCIFEST. Supervisor berasal dari dosen dan sebagai penghubung antara pihak mahasiswa dengan pihak universitas.

- Ketua bertugas mengontrol semua bagian kepanitaan agar festival dapat berjalan sesuai rencana. Tidak hanya itu ketua ikut ambil bagian dalam semua seksi kepanitiaan sekaligus membuat keputusan.

- Wakil ketua membantu ketua dalam mendelegasikan tugas ke pihak panitia, sekaligus menyelesaikan urusan-urusan yang dapat diatasi tanpa ketua. 
- Sekretaris bertugas mengurus administrasi dan formulir pendaftaran peserta dan pelaksanaan acara. Di samping itu sekretaris juga membuat logo UCIFEST sebagai kop surat yang akan dipakai untuk surat-menyurat dengan pihak-pihak terkait festival film. Sekretaris juga mengurus sertifikat bagi pihak juri, pemenang, dan panitia yang terlibat, serta membuat laporan kerja sebagai bentuk pertanggung jawaban kepada pihak universitas dan sponsor.

- Bendahara bertugas merancang kebutuhan dana, mengumpulkan dana, dan mengurus segala hal yang berhubungan dengan pemasukan dan pengeluaran. Bendahara dibantu sekretaris membuat Memorandum of Understanding (MoU) dengan berbagai pihak seperti sponsor dan media partner.

- Seksi Konsumsi bertugas menyediakan konsumsi dan logistik bagi seluruh panitia, juri dan peserta yang terlibat. Selain itu seksi konsumsi juga mempunyai hak untuk berjualan dan membuka stand untuk mengumpulkan dana.

- Seksi Teknis bertugas mempersiapkan kebutuhan teknis di tempat penyelenggaraan acara, disamping itu tim teknis juga mengecek kelayakan materi film dan suara sebelum proses pemutaran film dilaksanakan. Tidak hanya itu tim teknis juga membuat dan mengedit video untuk masing-masing kategori program, termasuk bumper.

- Seksi Acara, melakukan kurasi atas film-film dari peserta, membuat program pemutaran film, mempersiapkan acara seminar. Seksi acara dibantu supervisor membuat program-program pemutaran dalam festival film. Menentukan tim juri dalam setiap kategori dan mempersiapkan acara malam penghargaan.

- Seksi Publikasi bertugas mempublikasikan acara melalui media online dan offline, mendesain dan mencetak materi publikasi, menyebarkan materi publikasi, membuat formulir pendaftaran karya film di festival. Seksi publikasi juga menjalin hubungan dengan media partner dan menyiapkan press release.

- Seksi House and Usher bertugas mengatur dekorasi, membuat peraturan saat festival berlangsung, menjaga ketertiban penonton. Tim ini juga harus menjamu undangan-undangan khusus dan memberikan arahan untuk menuju ke lokasi acara.

- Seksi Dokumentasi bertugas mendokumentasikan acara festival film UCIFEST sekaligus mengedit dan memberikan laporan berupa foto dan video kepada bendahara. Laporan ini nantinya akan dicantumkan dalam laporan kerja sebagai bentuk pertanggung jawaban acara.

Struktur seperti ini yang terlihat pada Figure 6, umum ditemukan dalam berbagai festival film yang diinisiasi oleh mahasiswa. Pada pelaksanaan UCIFEST satu sampai tiga, jumlah mahasiswa film yang sedikit mempengaruhi jumlah panitia. Hal ini menyebabkan satu orang merangkap kerja dalam dua sampai tiga divisi.

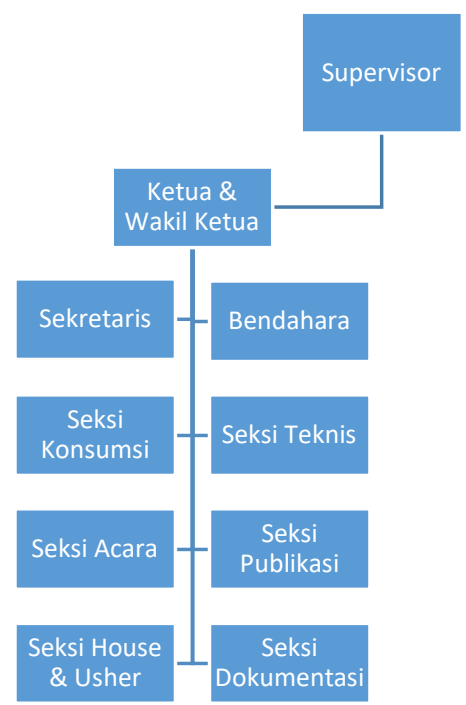

Fig. 6. Struktur organisasi UCIFEST 1 - 6 
Pola kerja dari sistem ini yaitu dari atas kebawah, ketua panitia membagi seluruh tim nya dalam beberapa seksi dan mengejawantahkan tugas-tugas kepada koordinator seksi atau divisi yang ada dibawahnya. Kemudian koordinator mendelegasikan tugas kepada anak buahnya. Struktur organisasi ini dapat dilakukan dalam skala besar maupun kecil, namun semua keputusan akhir dibuat oleh ketua. Baik keputusan dalam bidang artistik maupun program acara. Keputusan akhir yang dibuat oleh ketua lalu disampaikan ke koordinator masing-masing seksi dan dilaksanakan anak buah, memakan waktu yang cukup lama. Hal ini menjadi kendala ketika sebuah event atau festival bertumbuh besar dan makin banyak orang-orang yang dilibatkan. Namun seiring berkembang festival film UCIFEST dan dibentuknya mata kuliah festival film membuat perubahan dalam struktur organisasi panitia. Pengetahuan tentang festival film yang menyeluruh, membuat struktur kepanitiaan UCIFEST diubah. Struktur panitia UCIFEST saat ini yang berbeda dari sebelumnya terlihat pada Figure 7.

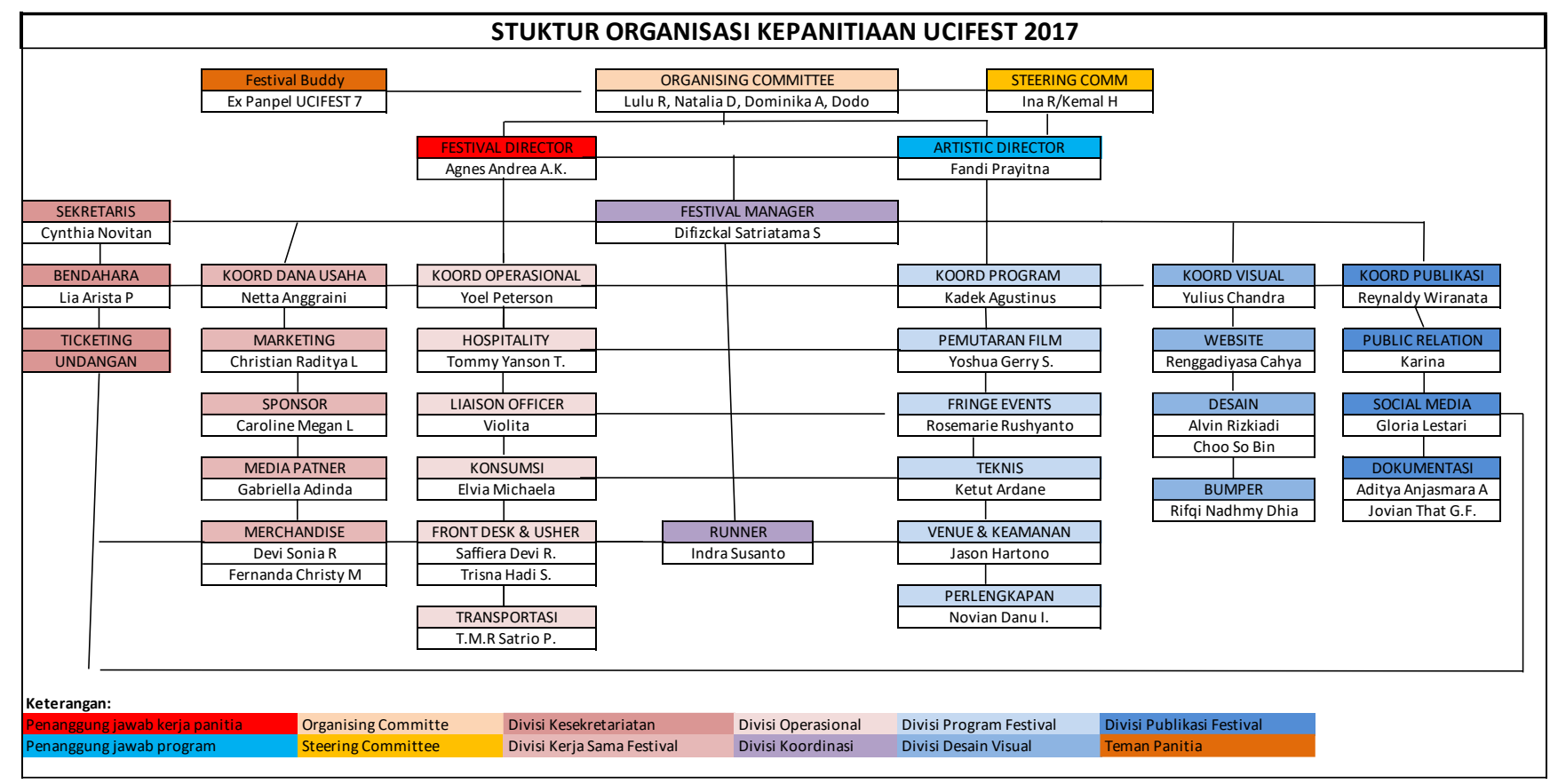

Fig. 7. Struktur Organisasi Kepanitiaan UCIFEST 2017

- Steering Committee berperan sebagai konsultan artistik acara festival film UCIFEST dan sebagai wakil dari penyelenggara festival Universitas Multimedia Nusantara (UMN). Steering committee terdiri dari dosen-dosen program studi Film di UMN.

- Organizing Committee bertugas mensupervisi kerja dari working committee atau kepanitian UCIFEST. Selain itu memastikan kerja panitia sesuai dengan standar kerja yang berlaku.

- Festival Director berperan dalam menentukan arah, tujuan, dan sasaran festival. Festival director juga bertindak sebagai penanggung jawab seluruh kegiatan yang berlangsung selama pelaksanaan festival film UCIFEST. Beberapa tugas penting dari festival director, yaitu membuat proposal bersama artistic director, menyusun keperluan administrasi dan suratmenyurat bersama sekretaris, menyusun rencana anggaran dan melakukan kontrol terhadap pengeluaran bersama bendahara, mengkoordinasi seluruh kerja panitia dibantu oleh festival manager, membantu koordinator sponsor mempresentasikan festival film UCIFEST kepada calon sponsor, bertindak sebagai programmer acara festival bersama artistic director, sebagai perantara komunikasi antara panitia UCIFEST dengan steering committee dan pihak universitas, membuat laporan kerja mingguan bagi organizing committee, berkoordinasi dengan artistic director untuk redaksi materi publikasi, seperti banner, poster, rundown acara, print ad material dan undangan, menyusun laporan kerja bersama sekretaris. 
- Bendahara adalah penanggung jawab keuangan festival. Bendahara dan festival director menyusun anggaran festival. Disamping itu bendahara juga mengontrol serta mencatat pengeluaran sesuai rencana anggaran, menyiapkan tanda bukti pengeluaran dana.

- Sekretaris bertanggung jawab atas sekretariat dan administrasi. Dalam festival film UCIFEST, sekretaris juga mengkoordinir penjualan tiket bersama bendahara, merchandise, front desk dan social media. Sekretari juga bertugas membantu festival director dan artistic director dalam pengumpulan data film, tamu, pengisi acara dan pihak yang berkepentingan dengan festival.

- Festival Manager bertanggung jawab terhadap koordinasi antar koordinator masing-masing divisi, baik selama persiapan, pelaksanaan, hingga setelah festival. Festival manager juga menyusun timeline kerja panitia berdasarkan masukan dari strategi kerja seluruh divisi panitia dan mengkoordinir kerja antar koordinator sesuai timeline.

- Artistic director bertanggung jawab terhadap program festival, menentukan film yang sesuai dengan karakteristik festival serta membuat program festival, termasuk program-program pendukung (fringe event).

- Program Director bertanggung jawab pada pelaksanaan seluruh acara festival. Beberapa tugas program director, yaitu menyiapkan dan mengirimkan formulir pendataan film bekerja sama dengan sekretaris, membantu artistic director mempersiapkan materi film untuk proses seleksi, bekerja sama dengan artistic director dalam menyusun program dan jadwal acara, bekerjasama dengan festival manager dalam menjalankan persiapan acara hingga acara berlangsung, mengkoordinir dan bertanggung jawab atas kerja seksi pemutaran film, fringe events, teknis, venue-keamanan dan perlengkapan, menyusun laporan program festival.

- Divisi Teknis bertanggung jawab dalam mempersiapkan materi pemutaran, mulai dari film hingga bumper festival. Selain itu divisi teknis melakukan screening test dan pengecekan terhadap audio sebelum program pemutaran film berlangsung.

- Designer bertanggung jawab terhadap desain utama dan desain seluruh materi publikasi dan produksinya.

- Koordinator Bumper bertugas membuat trailer dan bumper untuk festival film UCIFEST.

- Public Relation Manager bertanggung jawab terhadap komunikasi media, seperti menyiapkan press kit, mendata dan mengundang media dalam konferensi pers. Selama pelaksanaan festival, public relation manager bekerja sama dengan seksi hospitality menyambut tamu yang hadir, khususnya dari kalangan media.

- Social Media Officer bertanggung jawab atas akun social media festival. Seksi ini berperan dalam publikasi acara festival dan mengundang penonton dari khalayak umum.

Dalam struktur kepanitiaan di atas terdapat empat posisi penting, yaitu organizing committee, festival director, festival manager dan program director. Pucuk kepemimpinan tidak lagi berada di ketua dan wakil ketua tetapi di festival director, festival manager, dan program director. Ketiga tokoh ini lalu mendelegasikan tugas kepada masing-masing divisi dibawahnya. Masing-masing dapat membuat keputusan sesuai dengan kesepakatan dan ketentuan yang sudah dibuat sebelumnya. Struktur seperti ini memudahkan dalam koordinasi dan pelaksanaan tugas dilapangan. Selain itu komunikasi dari tim bisa disampaikan ke koordinator yang lalu akan disampaikan ke festival director, festival manager, atau program director sesuai dengan ranahnya masing-masing. Organizing committee dan steering committe menerima laporan dari masing-masing pemimpin, jika ada masalah yang menyangkut institusi organizing committee memberi arahan atau nasihat dalam pelaksanaan festival. Arahan yang diberikan biasanya menyangkut masalah legal dan copyrights dalam pelaksanaan festival film. Sejauh ini diantara festival film kampus yang diadakan oleh universitas di Indonesia yang menerapkan struktur organisasi kepanitiaan seperti diatas baru UMN. Struktur seperti diatas sangat efektif jika memiliki banyak anggota. Sehingga masing-masing anggota dapat fokus terhadap bidang pekerjaannya masing-masing. 


\section{Kesimpulan}

Berdasarkan pemaparan diatas festival film yang diselenggarakan dibawah institusi dan terlaksana di kampus dapat bertahan, karena adanya beberapa faktor seperti estafet kepemimpinan dari angkatan senior kepada angkatan dibawahnya. Tradisi estafet kepemimpinan dan keterlibatan mahasiswa baru dalam organisasi festival membentuk regenarasi panitia dari masing-masing angkatan. Selain itu mahasiswa yang bersifat kompetitif membutuhkan wadah untuk memamerkan karya mereka dan mengasah kemampuan dalam membuat film. Festival film kampus yang diadakan mahasiswa juga terbentuk karena jiwa mahasiswa yang aktif dan independen dalam menjalin relasi dan koneksi dengan sesama mahasiswa. Koneksi yang terbentuk memperkokoh sekaligus memperluas jaringan dari satu festival film ke festival film lainnya. Faktor lainnya yang tidak kalah penting dalam bertahan sebuah festival film kampus, yaotu adanya institusi yang menaungi acara festival. Institusi atau universitas tidak hanya menaungi tetapi juga memberikan dukungan baik finansial maupun tempat pelaksanaan festival. Perubahan struktur organisasi mungkin terjadi demi efisiensi dan efektifitas kinerja dari panitia-panitia yang terlibat. Festival film menjadi jalur distribusi alternatif yang menjawab permasalah bagi film-film pendek karya mahasiswa. Festival film kampus juga menjadi bagian ekosistem dalam industri perfilman.

\section{References}

Bachmann, Gideon. 2000. "Insight into the Growing Festival Influence: Fest Vet Discusses 'Wholesale'and 'Retail'Events." Variety. Com 28. Available at: Google Scholar

Banjaransari, Tunggul. 2019. "Modified Film Form in Reference to Contextual 3-D Filmmaking: Challenging the Monopoly of Film Form and Dissemination of Knowledge in Indonesia." International Journal of Visual and Performing Arts 1 (2): 53-59. https://doi.org/10.31763/viperarts.v1i2.15.

Jesika Ismail. 2017. “Daftar Festival Film Pendek Yang Wajib Kalian Ikuti.” Studio Antelope. 2017. https://studioantelope.com/daftar-festival-film-pendek-yang-wajib-kalian-ikuti/. Available at: studioantelope.com

Valck, Marijke De. 2007. Film Festivals: From European Geopolitics to Global Cinephilia. Amsterdam University Press. Available at: library.oapen.org 